\title{
Short Story Materials through Explanation, Space, Time of Writing Techniques in Elementary School
}

\author{
Ridha Shafa Aulia $^{1 *}$, Wahyu Sukartiningsih ${ }^{1}$ \\ ${ }^{1}$ Elementary Education, Surabaya State University, Surabaya, Indonesia \\ *Corresponding author.Email: ridhaauli20@gmail.com
}

\begin{abstract}
This study aims to train students' writing skills with short story material through the URW technique of writing. Thus, it can make it easier for students to find events according to stages. In this research with a development approach, when viewed in terms of writing skills, the ADDIE method uses. The results of this study are the process of developing teaching materials with a collection of short story material with short story material through writing URW techniques. arithmetic 17.748 $>t_{\text {table }} 1.734$, while the large class obtained $t_{\text {count }} 22.49>t_{\text {table }} 1.672$. Thus, it can be concluded that the development of teaching materials with a collection of short story material through writing URW technique, is effectively used as a short story writing skill with the URW technique for class V elementary school.
\end{abstract}

Keywords: development of teaching materials, URW Techniques, Writing Skills

\section{INTRODUCTION}

Indonesian language learning in elementary schools only uses teaching materials available in schools. According to previous research, the purpose of education is not only seen from the development of knowledge or cognitive alone but educational goals seen from the development of effective or attitudes that owned by students. Character and knowledge possessed by students must be considered in the process of developing learning [1]. To train students' writing skills, it is necessary to develop teaching materials that can be used so that students can easily acquire writing lessons. In particular, the difference between the development of teaching materials and the collection of short story materials through the writing of the URW technique with previous research lies in its application in learning, because there have not been too many previous studies that have developed textbooks with a collection of short story material using the URW technique. Previous research URW technique is one of the learning techniques for composing which is used to help and train students in writing for elementary school students, especially narrative frameworks [2]. The thing that underlies the development of teaching materials with a collection of short stories material through the URW writing technique is one way for teachers to provide basic guidance or training to students related to writing skills.
The Indonesian language approach with short stories material can make it easier for students to write short stories. Writing short stories can be easily done through writing techniques, namely by using the URW technique, which in this technique can help students in composing short stories.

Writing skill is one of the basic skills given to students. Teaching writing is needed by students because in learning to write students can write various things they want, one of which is to facilitate students' writing skills in the form of short stories. According to previous research that writing is a process of using both sides of the brain, which connects sentences, paragraphs can be understood logically [3]. This process, encourages the writer to think logically, systematically, and creatively which can communicate clearly to the reader. In connection with previous research, writing is one of the brain's working processes that can encourage writers to think logically, systematically, and creatively which can make it easier for readers to communicate clearly. The teaching materials that will be used are modified teaching materials with appropriate materials.

Teaching materials are one of the learning resources used by teachers in the learning process. Teaching materials are one of the guidelines used by teachers and students in conveying and obtaining learning. According to previous research, the learning process starts from the level of 
education using printed textbooks, because printed textbooks are easy to obtain [4]. This development of book teaching materials is one of the steps for an educator to provide teaching higher quality to students in writing skills. According to previous research, one of the functions of writing is as a communication tool that indirect. In the world of education, writing is one of the most important and main in teaching in elementary schools [5].

Theoretically, the development of teaching materials using short story materials through the URW technique can be supported by learning theory and effectiveness theory. Cognitive learning theories according to previous research that learning is an active mental form to achieve, remember and use knowledge [6]. In line with this opinion, effectiveness can be seen from four stages, namely: (1) the quality of learning can be seen in terms of presenting information to students, facilitating learning, and depending on the search for mastery, learning objectives. (2) The suitability of the level of learning is the extent to which the teacher can determine the level of readiness of students in obtaining new material. (3) Incentives, namely how much the teacher motivates students to work on and complete assignments from the material provided. (4) Time is the time given to complete the lesson [7].

During an interview with a teacher at SDN 1 Kutorejo, he learned that in the learning process the teacher only uses existing teaching materials to be used in learning, one of which is the K13 theme book. Therefore, at the time of the interview, the teacher did not develop teaching materials in the learning process, due to the limitations of the material that must be achieved in the learning design. Based on this information, the teacher only focuses on teaching materials that are already available without any development of teaching materials. Indonesian language learning shows the lack of students in telling stories when pouring stories into writing [8]. The explanation above can be interpreted that the development of short story teaching materials using the URW technique has been obtained from several studies as follows; the purpose of this research is to improve essay writing skills in subjects Indonesian language, and the type of research using research class action [9]. Thus it can be interpreted that the development of teaching materials using the URW technique can make it easier for students to write.

The problem found in the development of teaching materials in the form of books to train students' writing skills by sticking to the short story material, students can easily write short stories based on stories that are presented correctly.

\section{RESEARCH METHOD}

In developing teaching materials with short story material, you can use ADDIE in that method, it can provide stages that are in accordance with the research procedures of
Robert Maribe. This research uses various types of research and development.

One of the development models that can be used in development research is the ADDIE model (Analyze, Design, Development, Implementation, and Evaluation). The ADDIE model is one of the systematic learning design models. According to a previous study that ADDIE is a concept that develops products. In this case, the ADDIE concept is applied to build performance-based learning [7]. An educational philosophy to apply ADDIE learning must be innovative, authentic, and inspiring in that the concept of interactive development already exists in the social community. The purpose of ADDIE itself is as a fundamental process to create effective learning resources.

The instruments used to collect product quality data are: first, the validation sheet is shown to the expert lecturers of media development of teaching materials, the material validation sheet is shown to the material expert lecturers, to determine the validity of the teaching material media, the questionnaire (questionnaire) is one of the data collection questionnaires carried out by providing a presentation in the form of a written statement, a test sheet is used to collect data before the use of short story teaching materials, this observation sheet contains several learning implementations which include teacher and student activities delivered during the development of short story teaching materials. The data analysis technique is the data that has been obtained and then grouped with the same category and henceforth the data analysis is adjusted so that it becomes data that is relevant to the type of data that exists. In this development research, the data analysis techniques used are qualitative and quantitative techniques used in analyzing the data. The results of the material validation questionnaire were obtained, the product trial subjects were carried out by media experts and elementary school students. The data that has been obtained is used to analyze the data on the development of students who have used the media and those who have not used learning media. In this development research, the subject of testing the practicality of textbooks was validation, while collecting data on student learning outcomes in large classes was used to test the effectiveness of using textbook media in learning to write narrative frameworks for students. The results of the practicality of textbook media can be analyzed through student achievement in students in a study.

\section{RESULT AND DISCUSSION}

Development of teaching materials using short story material through writing URW techniques using the ADDIE method, which includes the stages of Analysis (Analyze), Design (Design), Development (Development), Implementation (Implementation), Evaluation (Evaluation). Because in the research process there are several obstacles 
in the study there are several stages that are not in accordance with the previous one [10]. Therefore, it can be maximized properly in the research process carried out. All development processes can be carried out by researchers as follows:

\subsection{Analyze}

The analysis stage is carried out in the form of an analysis stage to obtain data, through an analysis of one problem that exists in the school. the analysis stage includes three stages as follows: (1) Competency Analysis, Competency analysis is carried out by looking at the material presented in the learning process by looking at some story writing skills during Indonesian language learning. (2) Characteristics Analysis, the characteristic analysis is carried out by looking at the students when following the ongoing learning. (3) Student Material Analysis. Material analysis is carried out based on the results of competency analysis and student analysis.

\subsection{Design}

The design or design stage is the next step after conducting the analysis stage. Based on the data obtained after analyzing learning to write short stories, with the theme of natural disasters that tell the events of natural disasters in Indonesia and how to deal with disasters that occur. Thus, students need to practice some skills to write short stories so that learning becomes innovative learning. It can be seen that some students are only able to tell with the imagination they have, while others some students do not understand the story they are going to write.

\subsection{Development}

The development step, at this stage development, is the stage where it starts with the product as a whole. The stages of development begin with several of them:

1) Designing learning plans according to the needs and objectives of the learning to be delivered.

2) Designing learning designs, starting from compiling the syllabus, lesson plans, grids and finally developing teaching materials.

3) The completed design can serve as a guide for compiling the development of teaching materials to practice writing skills using the URW technique.

4) Designing the front cover and back cover, and designing the contents of the book that will be given to students.

5) Design a short story, based on a predetermined topic.
6) Adjust the writing of short stories, and provide a few pictures to attract students' interest.

7) Look for examples of pictures of natural disasters according to the stories contained in the book.

8) Placing the images obtained in accordance with the existing story.

9) After designing the front and back covers according to the sketch depicted.

10) Entering the stage of providing colors that match the topic in the story.

11) After all the designs meet the criteria, then they are combined into one to become a complete book.

12) After the checking process starts from the writing in the book and the cover used has met the desired standard, it can be distributed to students.

\subsection{Implementation}

At this stage, the materials are applied in learning in primary school classrooms especially V. At this stage to obtain data on the practicality and effectiveness of teaching materials for learning. This activity starts from two classes as follows:

1) Test in small class The trial

This first stage requires 21 students in class V SDN Kutorejo I Kertosono. On a small scale using the VA class as the first trial sample, by giving post-test, pre-test, and distributing questionnaires to each student. Thus, it aims to determine the feasibility of developing teaching materials and to find out whether several products must be improved to produce the expected product.

Table 1. big class test

\begin{tabular}{|c|c|c|c|c|}
\hline \multirow{3}{*}{ Total } & \multicolumn{4}{|c|}{ Table Column Head } \\
\cline { 2 - 5 } & $\begin{array}{c}\text { pre-test \& } \\
\text { post-test }\end{array}$ & Md & Score & Sig \\
\hline 21 & 11,85 & 17,89 & 348 & 17,748 \\
\cline { 2 - 2 } & 14,50 & & & \\
\hline
\end{tabular}

Based on the calculation of the t-test formula, the results of ${ }_{\text {count }}=17,748$ while $t_{\text {table }}$ with a significant level of $5 \%$ or $=0.05$ with the provisions of degrees of freedom $\mathrm{df}$ $=\mathrm{n}-1=19-1=18$, so the value of $\mathrm{t}_{\text {table }}=1.734$. This shows that $\mathrm{t}_{\text {arithmetic }}=17.748>\mathrm{t}_{\text {table }}=1.734$ then there is an increase in student learning outcomes by using the development of teaching materials with short story material.

2) Large Class Test the large

Class test is the stage where the development of teaching materials will be applied to the real class. The 
large-scale trial was carried out in the same elementary school but with different groups, namely at SDN 1 Kutorejo Kertosono in class VB with a total of 65 students. At this stage, a pre-test was distributed to students to determine the student's initial abilities and then explained beforehand to students before students did the book development exercise given. Then students are given a questionnaire to find out the practicality of the teaching materials developed.

Based on the evaluation carried out at this stage, it can be seen during small-scale trials, by making direct observations to students regarding the development of the given media. Therefore, at the small-scale trial stage, deficiencies were found, before being given to large classes or field trials. From the results carried out in small classes, it can be seen that there is no shortage of media used in the learning process. The application given to small classes proves that with a total of 21 students, it is proven that the use of developing teaching materials is very effective in training to compose a story.

\subsection{Evaluation}

At the evaluation stage, there are two stages, namely, formative evaluation and summative evaluation. Formative evaluation is a combination of the previous stages in ADDIE [10]. The results of each evaluation of the five stages are used as a reference to proceed to the next stage. Summative evaluation is through student pre-test and posttest. Summative evaluation is used to measure the achievement of the objectives of developing teaching materials in learning.

\section{DATA ANALYSIS}

The validity of the product development of short story writing skills was obtained from the validation data of teaching material experts and linguists. As for the graphics and presentation, it is given to the design expert to validate. Each of the validated experts received input and revision twice to obtain the desired results and could be tested in the field.

Table 2. material validation results, language, presentation, and graphic

\begin{tabular}{|l|c|c|c|}
\hline \multirow{3}{*}{ Aspect } & \multicolumn{3}{|c|}{ Table Column Head } \\
\cline { 2 - 4 } & Question points & $\begin{array}{c}\text { Rating } \\
\text { indicators }\end{array}$ & Score \\
\hline Contents & 5 & 5 & 22 \\
\hline Language & 5 & 5 & 22 \\
\hline Presentation & 8 & 8 & 36 \\
\hline Graphic & 8 & 8 & 36 \\
\hline
\end{tabular}

Based on the table from each validated expert, obtained the results of a percentage range of $81 \%-100 \%$ with a very valid/feasible to use information. Thus the development of teaching materials (books) is said to be suitable for use in learning [11].

Table 3. Big class test

\begin{tabular}{|c|c|c|c|c|}
\hline \multirow[t]{2}{*}{ Total } & \multicolumn{4}{|c|}{ Table Column Head } \\
\hline & pre test \& post test & Md & Score & Sig \\
\hline \multirow[t]{2}{*}{58} & 3505 & \multirow[t]{2}{*}{15,25} & \multirow[t]{2}{*}{1521} & 22,49 \\
\hline & 4390 & & & \\
\hline
\end{tabular}

Based on the calculation of the t-test formula, the results of $t_{\text {count }}=22.49$ while $t_{\text {table }}$ with a significant level of $5 \%$ or $=0.05$ with the provisions of degrees of freedom $\mathrm{df}$ $=\mathrm{n}-1=58-1=57$, so the value of $\mathrm{t}_{\text {table }}=1.672$. This shows that $\mathrm{t}_{\text {arithmetic }}=22.49>\mathrm{t}_{\text {table }}=1.671$ then there is an increase in student learning outcomes by using the development of teaching materials with short story material.

Based on the explanation above, it can be concluded that the development of teaching materials can make it easier for students to write short stories, which initially had some incomplete grades after an explanation of how to develop writing skills using the URW technique the scores obtained by students met completeness [12].

This completeness can be proven by the acquisition of pre-test scores with a t-test value of 5.50, meaning that the $\mathrm{t}$-count value is $>$ than the $\mathrm{t}$-table, as well as the results from the post-test with a score of 8.756 .

This, the results of both pre-test and post-test mean that the development of teaching materials helps to compose short stories easily. Inline that opinion effectiveness can be seen from four stages, namely: (1) the quality of learning can be seen in terms of presenting information to students, making it easy to learn, and depending on the search for mastery, learning objectives. (2) The suitability of the level of learning is the extent to which the teacher can determine the level of readiness of students in obtaining new material. (3) Incentives, namely how much the teacher motivates students to work on and complete assignments from the material provided. (4) Time is the time given to complete the lesson [7].

The explanation contained above is that the results of the pre-test and post-test are as follows: the calculation of the t-test formula obtained the results of $\mathrm{t}_{\text {count }}=17,748$ while $t_{\text {table }}$ with a significant level of $5 \%$ or $=0.05$ with the provisions of degrees of freedom $\mathrm{df}=\mathrm{n}-1=19-1=18$, so the value of $t_{\text {table }}=1.734$. This shows that $t_{\text {arithmetic }}=17.748$ $>t_{\text {table }}=1.734$ then there is an increase in student learning outcomes by using the development of teaching materials with short stories material. While the post-test calculation of the t-test formula obtained the results of $t_{\text {count }}=22.49$ while $t_{\text {table }}$ with a significant level of $5 \%$ or $=0.05$ with the provisions of degrees of freedom $\mathrm{df}=\mathrm{n}-1=58-1=57$, so the value of $t_{\text {table }}=1,672$. This shows that $t_{\text {arithmetic }}=22.49>$ $\mathrm{t}_{\text {table }}=1.672$ then there is an increase in student learning 
outcomes by using the development of teaching materials with short stories material.

The problems that exist above, the solution can be given as follows; offered to develop teaching materials for providing writing skills training [13]. In line with further research that teaching materials are not just materials or information but roles and principles that have their functions in teaching material. It can be seen in previous research, teaching materials have a goal, namely in learning to contain material, content in subjects in the form of concepts, principles, or rules that cover the entire material to be used, which can be realized in the development of teaching materials for short story writing skills using the URW technique [14]. Opinions of previous research writing can be related to a communication activity that uses language as a medium in the form of writing on letters that have meaning with all its completeness [15].

\section{CONCLUSION}

The development of teaching materials using short story material through writing the URW class V technique using the ADDIE method was declared feasible from the results of the validation test by the two validates, each of which obtained $80 \%-100 \%$ in the very valid category used. Based on the results of developing writing skills teaching materials using short story material through the URW technique in grade 5 elementary schools, it can be seen from various aspects, as follows: (1) Produce products in the form of student textbooks, (2) Train students in writing short stories easily [6].

Based on the results presented, the first small class was carried out with a total of 21 students in one class, the results of the pre-test and post-test with a score obtained $t_{\text {count }} 17,748$ $>t_{\text {table }} 1,734$. While in the implementation of the large class there are 58 students, the results of the post-test and pre-test with the acquisition score obtained $t_{\text {count }} 22.49>t_{\text {table }} 1.672$. Thus, it can be interpreted that the development of teaching materials with a collection of short story material through writing URW techniques can make it easier for students to assemble a short story framework. The results of developing teaching materials using short story material through the writing of the URW technique in this study can be used as a reference in further research.

\section{ACKNOWLEDGMENT}

We thank a lot Unesa for permission and grant funding assistance as presenter of ICRACOS 2021.

\section{REFERENCES}

[1] H. J. Saputra, "Pengembangan bahan ajar untuk menumbuhkan nilai karakteristik peduli lingkungan," 2017, vol. 4, p. $\quad$ 1, doi: http://journals.ums.ac.id/index.php/ppd/article/view/

[2] H. J. Priyanto, "Berlatih Mengarang Dengan Metode URW Mengembangkan Imajinasi," Surakarta: FKIP UMS, 2009.

[3] H. Dalman, Keterampilan Menulis, Cetakan ke. Depok: PT. Rajagrafindo, 2016.

[4] a. sudarmanto Widyastuti, perencanaan pembelajaran. Jakarta: yayasan kita menulis, 2017.

[5] S. Akhaidah, Pembinaan kemampuan menulis bahasa indonesia. Bandung: Erlangga, 2004.

[6] A. Suprijono, CooperativeLearning Teori \& Aplikasi PAIKEM, Edisi Revi. Yogyakarta: PUSTAKA BELAJAR, 2015.

[7] R. e Slavin, Education Psychology Theory and Practice. new york, 2009.

[8] N. Wijianingsih, "Pengembangan Bahan Ajar Berbasis Budaya Lokal,” vol. 2, no. 2502-47x, 2017.

[9] H. Sukma, "Optimalisasi Keterampilan Berbicara Dengan Teknik URW Pada Kelas Awal di Sekolah Dasar," no. 2477-636X, pp. 1-6, 2015, [Online]. Available: https://scholar.google.com.

[10] R. maribe Branch, Instructional Design: The ADDIE Aproach. New York, 2009.

[11] Sugiono, Metode penelitian kualitatif, kuantitatif, dan $R \& D$. Yogyakarta: CV.Altabeta, 2007.

[12] Arikunto, Metode Penelitian. Jakarta: Gramedia Utama, 2014.

[13] M. P. Nana, Pengembangan Bahan Ajar. kelaten jawa tengah: Lakeisha, 2019.

[14] A. H. Hermawan, Pengembangan Bahan ajar. Jakarta, 2017.

[15] M. P. Munirah, Pengembangan Menulis Paragraf. sleman: CV BUDI UTAMA, 2015. 